\title{
Hubungan Tingkat Kosmopolitan dan Karakteristik Inovasi dengan Sikap Peternak Sapi Potong pada Pengobatan Luka Traumatik Menggunakan Salep Ekstrak Tanaman Yodium
}

\section{Correlation of Level of Cosmopolitan and Characteristics of Innovation with Attitude of Cattle Livestock in Traumatic Wound Treatment Using Iodine Plant Extract Ointment}

\author{
Budi Purwo Widiarso ${ }^{1, *}$, Chichika Jeni ${ }^{2}$, Nurdayati ${ }^{2}$
}

\author{
${ }^{1}$ Program Studi Teknologi Produksi Ternak Politeknik Pembangunan Pertanian Yogyakarta-Magelang \\ ${ }^{2}$ Program Studi Penyuluhan Peternakan dan Kesejahteraan Hewan Politeknik Pembangunan Pertanian Yogyakarta-Magelang \\ ${ }^{*}$ E-mail Korespondensi: budipw2000@yahoo.com
}

Diterima: 7 Juni 2021 | Disetujui: 3 Januari 2022 | Publikasi Online: 6 Januari 2022

\begin{abstract}
The research was conducted in Mangunrejo Village, Tegalrejo District, Magelang Regency. The purpose of the study was to determine the relationship between the level of cosmopolitan and innovation characteristics with the attitude of beef cattle breeders, in the treatment of traumatic wounds using Iodine plant extract ointment. Data were collected by means of observation and questionnaires. The variables observed were the level of cosmopolitan, innovation characteristics and attitudes. The study design used is the One Shot Case Study method. The population used is the Amanah farmer/livestock group with a sample of 32 people determined using the saturated sample technique. Analysis of the data used is descriptive analysis and statistical analysis (simple correlation or Pearson product moment and multiple correlation). The results showed a significant relationship $(p<0.05)$ between the cosmopolitan level and the attitude of goat breeders with a correlation coefficient (ryxl) of 0.395 (positive), indicating a significant relationship $(p<0.05)$ between the characteristics of innovation and the attitudes of cattle farmers. cut on the treatment of traumatic wounds using an iodine plant extract ointment and the correlation coefficient (ryx2)=0.355 (positive). Taken together, there was also a significant relationship ( $p$ $<0.05)$ between the level of cosmopolitan and innovation characteristics with the attitude of beef cattle farmers on the treatment of traumatic wounds using plant extract ointment (Ryxlx2) of 0.473 (positive). This study can be concluded that there is a relationship between the level of cosmopolitan and innovation characteristics with the attitude of beef cattle farmers in the treatment of traumatic wounds using plant extract ointment.
\end{abstract}

Keywords: Attitudes, correlations, cosmopolitan levels, cow, innovation characteristics

\section{ABSTRAK}

Penelitian dilakukan di Desa Mangunrejo Kecamatan Tegalrejo Kabupaten Magelang. Tujuan penelitian adalah mengetahui hubungan tingkat kosmopolitan dan karakteristik inovasi dengan sikap peternak sapi potong, pada pengobatan luka traumatik menggunakan salep ekstrak tanaman yodium. Pengumpulan data dilakukan dengan cara observasi dan pemberian kuesioner. Variabel yang diamati yaitu tingkat kosmopolitan, karakteristik inovasi dan sikap. Rancangan kajian yang digunakan adalah metode One Shot Case Study. Populasi yang digunakan adalah kelompok tani/ternak Amanah dengan sampel berjumlah 32 orang yang ditetapkan menggunakan teknik sampel jenuh. Analisis data yang digunakan adalah analisis deskriptif dan analisis statistik (korelasi sederhana atau pearson product moment dan korelasi ganda). Hasil penelitian menunjukkan hubungan yang signifikan $(\mathrm{p}<0,05)$ antara tingkat kosmopolitan dengan sikap peternak kambing dengan koefisien korelasi sebesar 0,395 (positif), menunjukkan hubungan yang signifikan $(\mathrm{p}<0,05)$ antara karakteristik inovasi dengan sikap peternak sapi potong pada pengobatan luka traumatik menggunakan salep ekstrak tanaman yodium dan koefisien korelasi $=0,355$ (positif). Secara bersama- sama juga memiliki hubungan yang signifikan $(p<0,05)$ antara tingkat kosmopolitan dan karakteristik inovasi dengan sikap peternak sapi potong pada pengobatan luka traumatik menggunakan salep ekstrak tanaman yodium sebesar 0,473 (positif). Penelitian ini dapat disimpulkan bahwa terdapat hubungan antara tingkat kosmopolitan dan karakteristik inovasi dengan sikap peternak sapi potong pada pengobatan luka traumatik menggunakan salep ekstrak tanaman yodium.

Kata kunci: Hubungan, karakteristik inovasi, sapi potong, sikap, tingkat kosmopolitan

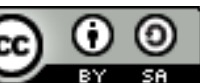




\section{PENDAHULUAN}

Sapi potong, ternak kambing dan domba berpotensi tinggi jika pemeliharaan dan perawatan yang baik sehingga diperoleh hasil yang baik pula (Widiarso et al., 2018) Secara keseluruhan, produktivitas sapi potong masih sangat memprihatinkan karena volumenya masih jauh dari target yang diperlukan konsumen. Permasalahan ini disebabkan oleh produksi daging yang masih rendah. Factor yang menyebabkan volume produksi daging masih rendah antara lain populasi yang juga rendah(Sugeng, n.d.). Selain itu, juga dapat disebabkan oleh infeksi nematode yang menyebabkan penurunan berat badan dan pertumbuhan terhambat. (Widiarso BP et al., 2021)

Sapi potong di Indonesia sangat bermanfaat dan banyak dibutuhkan oleh konsumen, maka perlu diperhatikan perkembangbiakannya secara intensif. Dalam konteks ini kesehatan sapi potong merupakan hal yang sangat penting, terkait dengan keberlangsungan populasinya di Indonesia. Oleh karena itu, peran tenaga peternakan sangat diperlukan untuk mengawasi, melaksanakan dan menghimbau mengenai cara menjaga kesehatan ternak, sehingga kesehatan ternak sapi potong potong di Indonesia dapat terjaga dan sapi potong dapat berkembang dengan baik (Widyaningrum, 2005)Hal yang dapat dilakukan yaitu, memberi pengetahuan kepada para tenaga peternakan tentang pentingnya kesehatan ternak sapi potong potong. Banyak peternak atau masyarakat yang tidak mengetahui bagaimana cara menjaga kesehatan pada ternak sapi potong potong, padahal hal ini sangat mempengaruhi pertumbuhan dan perkembangan sapi potong. Salah satu wilayah yang belum mengetahui pentingnya menjaga kesehatan sapi potong adalah Desa Mangunrejo.

Desa Mangunrejo merupakan salah satu desa yang termasuk ke wilayah Kecamatan Tegalrejo Kabupaten Magelang. Letaknya di sebelah timur Kabupaten Magelang. Desa Mangunrejo berbatas dengan wilayah sebelah Utara Desa Lebak dan Pucungsari, sebelah Timur Desa Gejagan dan Kajangkoso, sebelah Selatan Desa Kebonagung dan Japan, sebelah Barat Desa Donorejo Kecamatan Tegalrejo. Sebagian besar wilayah desa Mangunrejo adalah lahan pertanian. Selain berpotensi dibidang pertanian, Desa Mangunrejo juga sangat berpotensi dibidang peternakan, khususnya ternak sapi potong.

Berdasarkan hasil identifikasi wilayah di lapangan, mata pencaharian utama penduduk Desa Mangunrejo bergerak disektor pertanian dan peternakan. Komoditas pertanian meliputi holtikultura, palawija dan padi sedangkan untuk komoditas peternakan meliputi sapi potong, kelinci, dan ayam buras. Populasi sapi potong di Desa Mangunrejo termasuk yang terbesar di Kecamatan Tegalrejo. Banyaknya populasi sapi potong potong di Desa Mangunrejo menunjukkan bahwa hal ini berpotensi untuk dikembangkan. Adapun permasalahan yang terdapat di Desa Mangunrejo adalah masalah kesehatan, yakni sapi potong peternak mengalami luka dibagian kulit yang disebabkan oleh gesekan dengan benda-benda tajam. Oleh karena itu, peternak harus lebih memperhatikan aspek kesehatan sapi potong terutama pengobatan luka akibat goresan atau luka traumatik menggunakan inovasi salep ekstrak dari tanaman yodium. Hal ini sesuai dengan pendapat (Putri Cahyani et al., 2021) bahwa salep ekstrak memiliki efikasi hasil lebih baik daripada sediaan yang lainnya.

Teknologi Pengobatan Luka Traumatik Menggunakan Salep Ekstrak Tanaman Yodium merupakan salah satu inovasi yang dianggap baru bagi usaha ternak sapi potong. Sebuah inovasi dapat diterima oleh peternak apabila telah memenuhi lima kriteria yang menandai setiap gagasan atau cara-cara baru yang terkandung dalam inovasi tersebut. Gagasan tersebut terdiri dari: relative advantages, compatibility, complexity, trialability, dan observability (Rogers, 1996). Pengobatan Luka Traumatik Menggunakan Salep Ekstrak Tanaman Yodium pada dasarnya mudah untuk diaplikasikan karena relatif mudah untuk diterapkan, namun peternak sapi di Desa Mangunrejo masih belum menggunakan teknologi dikarenakan masih kurang pengetahuan peternak dalam pengobatan luka traumatik menggunakan salep ekstrak tanaman yodium.

Penyuluhan pada peternak sapi potong mempunyai tujuan agar dapat mengetahui cara pengobatan luka traumatik menggunakan salep ekstrak tanaman yodium. Interaksi pada kegiatan penyuluhan dengan peternak merupakan suatu pertanda adanya proses komunikasi. Komunikasi adalah suatu proses penyampaian informasi dari pemberi terhadap penerima pesan. Penyerapan informasi yang akan disampaikan pada peternak dipengaruhi oleh tingkat efektivitas komunikasi yang terjadi pada saat penyuluhan berlangsung. Indikator keberhasilan penyerapan infomasi dalam sebuah komunikasi dapat dilihat dari perubahan pengetahuan dan sikap yang ditimbulkan (Wiriaadmadja et al., 2016) 
Kosmopolitan merupakan sikap keterbukaan pandangan seseorang yang dapat dilihat dari karakteristik yang mempunyai hubungan dan pandangan yang luas dengan dunia luar maupun kelompok lainnya dan memiliki mobilitas yang tinggi (T. dan S. S. Mardikanto, 1982). Kosmopolitan dapat diketahui dari frekuansi pergi ke kota atau keluar kota kabupaten dan jarak perjalanan yang dilakukan, serta pemanfaatan media massa. Hasil penelitian yang dilakukan oleh (Suharyani \& Oktoriana, 2018) menunjukkan bahwa kosmopolitan responden berpengaruh signifikan terhadap keputusan pengelolaan usahatani yang dilakukan. Semakin tinggi tingkat kekosmopolitannya maka akan semakin tinggi tingkat penerapan teknologinya, semakin sering responden dalam mencari informasi yang berkaitan dengan kegiatan usahatani dan berpengaruh besar dalam penerapan teknologi pada usahataninya.

Berdasarkan hal tersebut, peternak Desa Mangunrejo harus mampu meningkatkan keterbukaan terhadap informasi-informasi yang berkaitan dengan usaha-usaha yang berhubungan dengan bidang peternakan. Berdasarkan hasil identifikasi potensi wilayah, penulis mengambil judul "Hubungan Tingkat Kosmopolitan dan Karakteristik Inovasi dengan Sikap Peternak Sapi potong Potong Pada Pengobatan Luka Traumatik Menggunakan Salep Ekstrak Tanaman Yodium di Desa Mangunrejo".

\section{METODE}

Penelitian dilaksanakan di Desa Mangunrejo, Kecamatan Tegalrejo, Kabupaten Magelang. Rancangan penelitian yang digunakan adalah One Shot Case Study, desain ini digunakan untuk meneliti peningkatan sikap peternak sapi potong pada ranah afektif dan psikomotorik. Menurut (Arikunto, 2013) desain ini peneliti hanya mengadakan treatment satu kali yang diperkirakan sudah mempunyai pengaruh, kemudian diadakan post-test. Populasi yang digunakan dalam pelaksanaan penelitian merupakan peternak sapi potong yang berdomisili di Desa Mangunrejo dan tergabung kedalam kelompok tani/ternak. Teknik pengambilan sampel pada penelitian ini menggunakan purposive sampling, yaitu pengambilan sampel dengan kriteria peternak sapi potong di Desa Mangunrejo, sehingga sampel yang digunakan adalah sebanyak 32 orang. Variabel penelitian yang diuji pada penelitian ini yaitu variabel dependen dan variabel independen. Variabel Independen yang digunakan dalam penelitian ini adalah Tingkat Kosmopolitan dan Karakteristik Inovasi. Tingkat Kosmopolitan adalah frekuansi pergi ke kota atau keluar kota kabupaten dan jarak perjalanan yang dilakukan, serta pemanfaatan media massa, sedangkan karakteristik Inovasi diukur melalui (a) keunggulan relatif, (b) tingkat kesesuaian, (c) tingkat kerumitan, (d) dapat dicoba, dan (e) dapat diamati. Variabel Dependen yang digunakan dalam penelitian ini adalah Sikap peternak peternak sapi potong terhadap inovasi (Y). Sikap peternak Sapi Potong terhadap adanya inovasi Pengobatan Luka Traumatik Menggunakan Salep Ekstrak Tanaman Yodium. Analisis data yang digunakan adalah analisis deskriptif dan analisis statistik. Analisis diskriptif digunakan untuk menganalisis data untuk mendeskripsikan data sampel dan tidak ingin membuat kesimpulan yang berlaku untuk populasi dimana sampel diambil. Proses penelitian ini dilakukan dengan cara memberikan post tes kepada 32 responden. Alat yang digunakan berupa kuisioner yang sebelum diberikan terlebih dahulu dilakukan uji validitas dan uji reliabilitas. Analisis statistik yang digunakan adalah korelasi pearson product moment sederhana dan korelasi berganda. Analiis pearson product moment sederhana digunakan untuk mencari hubungan masing-masing variabel independen dengan variabel dependen, rumus analisis pearson product moment sederhana sebagai berikut:

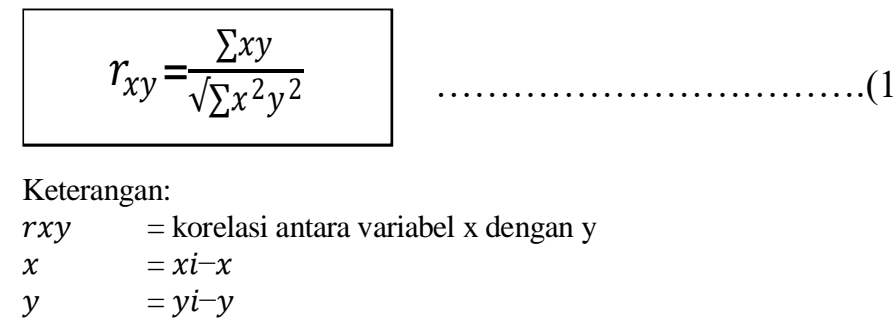

Analisis korelasi berganda digunakan untuk mencari kuatnya hubungan dua variabel independen secara bersama-sama atau lebih dengan satu variabel dependen. Rumus korelasi berganda sebagai berikut: 


$$
R_{y x_{1} x_{2}}=\sqrt{\frac{r_{y x 1}^{2}+r_{y x z}^{2}-2 r_{y x 1} r_{y x 2 r_{x \perp x 2}}}{1-r_{x 1 x_{2}}^{2}}}
$$

Keterangan:

Ryx $1 \times 2=$ korelasi antara variabel $\mathrm{X}_{1}$ dengan $\mathrm{X}_{2}$ secara bersama-sama dengan variabel $\mathrm{Y}$

ryx $1=$ korelasi Product Moment antara $\mathrm{X}_{1}$ dengan $\mathrm{Y}$

$r y x 2=$ korelasi Product Moment antara $\mathrm{X}_{2}$ dengan $\mathrm{Y}$

$r x 1 \times 2=$ korelasi Product Moment antara $\mathrm{X}_{1}$ dengan $\mathrm{X}_{2}$

\section{Uji Persyaratan}

Data yang dikumpulkan melalui kuesioner diubah dalam bentuk data skala interval, menggunakan Method of Successive Internal (MSI). Distribusi Normalitas Data merupakan hasil uji normalitas tes tingkat kosmopolitan dengan nilai signifikan lebih besar dari nilai $a=0,05(0,674>0,05)$, karakteristik inovasi dengan nilai $0,068>0,05$ dan sikap peternak dengan nilai $0,488>0,05$ sehingga data berdistribusi normal.

\section{HASIL DAN PEMBAHASAN}

\section{Karakteristik Responden}

Karakteristik responden merupakan penguraian deskripsi identitas responden menurut sampel penelitian yang telah ditetapkan. Tujuan dengan mendeskripsi karakteristik responden adalah memberi gambaran yang menjadi sampel penelitian. Karakteristik responden dalam kajian ini meliputi umur, tingkat pendidikan, dan pengalaman beternak.

\section{Umur}

Kategori umur menurut (Khasanah, 2008) dibedakan menjadi lima, yang pertama $\leq 25$, kedua 26,35 tahun, ketiga 36-45 tahun, keempat 46-55 tahun, kelima > 55. Karakteristik responden berdasarkan umur dalam kegiatan tugas akhir ini dapat dilihat pada Tabel 1 berikut:

Tabel 1. Responden Menurut Umur

\begin{tabular}{ccc}
\hline Umur (tahun) & Jumlah (orang) & Persentase (\%) \\
\hline$\leq 25$ & 0 & 0 \\
$26-35$ & 0 & 0 \\
$36-45$ & 2 & 6,25 \\
$46-55$ & 9 & 28,12 \\
$>55$ & 21 & 65,62 \\
\hline Jumlah & 32 & 100 \\
\hline
\end{tabular}

Berdasarkan Tabel 1 di atas diketahui bahwa umur responden sebagian besar masuk dalam kisaran > 55 tahun sebanyak 21 orang dengan indeks persen sebesar 65,62\%, kemudian kisaran 46-55 tahun sebanyak 9 orang dengan indeks persen sebesar 28,12\%, lalu kisaran 66-75 tahun sebanyak 7 orang dengan indeks persen sebesar 21,87\% dan kisaran 36-45 sebanyak 2 orang dengan indeks persen sebesar 6,25\%. Menurut (Junaidi, 2007) menyatakan bahwa umur 15-65 tahun dikatakan penduduk umur produktif adalah yang melaksanakan produksi dari segi ekonomi, dimana segala kebutuhannya ditanggung mereka sendiri dan mampu memenuhi hidupnya sendiri. Pernyataan tersebut mendukung dengan umur responden dengan kisaran 15-65 tahun sebanyak 24 orang dengan indeks persen sebesar $75 \%$.

\section{Tingkat Pendidikan}

Tingkat Pendidikan mempengaruhi pola pikir masyarakat, masyarakat dengan tingkat pendidikan relatif tinggi umumnya lebih dinamis dan kreatif serta juga akan mempengaruhi pola pikir peternak terhadap keputusan dalam menerapkan sebuah inovasi. Karakteristik responden berdasarkan tingkat pendidikan dalam kegiatan tugas akhir ini dapat dilihat pada Tabel 2. 
Berdasarkan Tabel 2 diketahui sebagian besar tingkat pendidikan responden masih tergolong rendah yaitu tamatan SD sebanyak 13 orang dengan indeks persen sebesar 40,62\% dan tamatan SMP sebanyak 11 orang dengan indeks persen sebesar 34,37\%, sedangkan untuk tamatan SMA sebanyak 7 orang dengan indeks persen sebesar $21,87 \%$ dan perguruan tinggi satu orang dengan indeks persen sebesar 3,12\%. Tingkat pendidikan tersebut memberikan dampak pada kemampuan dalam menerima sebuah inovasi. Hal tersebut sesuai dengan pendapat (T. Mardikanto, 2009) bahwa tingkat pendidikan yang dimiliki seseorang akan berpengaruh terhadap kemampuan belajar di tingkat pengetahuan tertentu untuk dapat memahami suatu teknologi/inovasi. Menurut (Padmowiharjo, 2002) yang menyatakan bahwa semakin tinggi tingkat pendidikan petani maka pola pikir juga semakin luas dan tentunya akan lebih cepat dalam merespon teknologi baru yang disampaikan.

Tabel 2. Responden Menurut Pendidikan

\begin{tabular}{|c|c|c|}
\hline Pendidikan & Jumlah (orang) & Persentase (\%) \\
\hline SD & 13 & 40,62 \\
\hline SMP & 11 & 34,37 \\
\hline SMA & 7 & 21,87 \\
\hline Perguruan Tinggi & 1 & 3,12 \\
\hline Jumlah & 32 & 100 \\
\hline
\end{tabular}

\section{Pengalaman Ternak}

Pengalaman beternak akan mempengaruhi peternak dalam menerima atau menolak suatu inovasi dalam menjalankan usahataninya. Kategori pengalaman beternak menurut (Irmayani, 2013)ada tiga, yang pertama $\leq 4$ tahun, kedua 5-10 tahun, ketiga $>10$ tahun. Karakteristik responden berdasarkan pengalaman beternak dalam kegiatan tugas akhir ini dapat dilihat pada Tabel 3 berikut:

Tabel 3. Responden Menurut Pengalaman Beternak

\begin{tabular}{ccc}
\hline Pengalaman Beternak (tahun) & Jumlah (orang) & Persentase (\%) \\
\hline$\leq 4$ & 1 & 3,12 \\
$5-10$ & 5 & 15,62 \\
$>10$ & 26 & 81,25 \\
\hline Jumlah & 32 & 100 \\
\hline
\end{tabular}

Berdasarkan Tabel 3 tersebut dapat diketahui bahwa rata-rata pengalaman beternak responden kisaran $\leq 4$ tahun yaitu sebanyak 1 orang dengan indeks persen sebesar 3,15\%, kemudian kisaran 5-10 tahun sebanyak 5 orang dengan indeks persen sebesar $15,62 \%$, selanjutnya kisaran $>10$ tahun sebanyak 26 orang atau dengan indeks persen sebesar $81,25 \%$. Hal tersebut sesuai dengan pendapat (Iskandar \& Arfa'i, 2007)yang menyatakan bahwa umur dan pengalaman beternak akan mempengaruhi kemampuan peternak dalam menjalankan usaha, peternak yang mempunyai pengalaman beternak lebih banyak akan selalu berhati-hati dalam bertindak. Selanjutnya didukung dengan pernyataan (Siregar, 2013) bahwa pengalaman dalam usaha ternak dapat mempengaruhi kemampuan dalam mengelola usaha ternak, dengan pengalaman yang cukup lama petani memiliki pemahaman yang baik terhadap usaha ternak yang dijalankannya.

\section{Tingkat Kosmopolitan}

Tingkat kosmopolitan peternak sapi potong di Desa Mangunrejo diukur berdasarkan hubungan atau interaksi peternak terhadap dunia luar di luar sistem sosialnya sendiri. Hasil Rekapitulasi jawaban responden tingkat kosmopolitan Desa Mangunrejo dapat dilihat pada Tabel 4 berikut: 
Tabel 4. Rata-Rata Tingkat Kosmopolitan

\begin{tabular}{lcc}
\hline \hline \multicolumn{1}{c}{ Parameter Kosmopolitan } & Rata-Rata & Persentase (\%) \\
\hline Frekuensi peternak menonton televisi dan mendengarkan radio & 17,3 & 35,02 \\
Frekuensi peternak membaca koran & 4,8 & 9,71 \\
Frekuensi peternak keluar dari desa tempat tinggalnya & 10,6 & 21,45 \\
Frekuensi peternak bertemu tokoh innovator & 6,7 & 13,56 \\
Frekuensi peternak mengikuti penyuluhan & 10 & 20,24 \\
\hline Jumlah & 49,4 & 100 \\
\hline
\end{tabular}

Berdasarkan Tabel 4 di atas dapat diketahui rata-rata nilai frekuensi peternak menonton televisi dan mendengarkan radio sebesar 17,3 atau sebesar $35,02 \%$, frekuensi peternak membaca koran sebesar 4,8 atau sebesar $9,71 \%$, frekuensi peternak keluar dari desa tempat tinggalnya 10,6 atau sebesar 21,45\%, frekuensi peternak bertemu tokoh inovator 6,7 atau sebesar 13,56\% dan frekuensi peternak mengikuti penyuluhan 10 atau sebesar 20,24\%. Rata-rata keseluruhan tingkat kosmopolitan dari 32 responden adalah 49,4 dengan kategori sedang. Hal ini dikarenakan rendahnya peternak dalam mendengarkan media elektronik berupa radio dan membaca media cetak. Intensitas penyuluhan dan frekuensi peternak mengakses informsi tidak berpengaruh secara langsung terhadap persepsi, sedangkan pengaruh secara tidak langsung dari intensitas penyuluhan melalui tingkat pengetahuan berpengaruh signifikan terhadap persepsi (Nurdayati et al., 2021)

\section{Karakteristik Inovasi}

Karakteristik inovasi adalah salah satu penentu dalam proses penerimaan suatu inovasi. Berikut adalah rekapitulasi jawaban responden karakteristik inovasi pada Tabel 5 berikut:

Tabel 5. Karakteristik Inovasi

\begin{tabular}{llc}
\hline \hline \multicolumn{1}{c}{ Variabel Pengukuran } & Skor & Interpretasi \\
\hline Keuntungan relatif (mengenai salep ekstrak tanaman yodium) & 379 & Baik \\
Kompatibilitas (kesesuaian inovasi dengan lokasi Tugas Akhir) & 202 & Cukup Baik \\
Kompleksitas (tingkat kerumitan inovasi) & 234 & Tidak Baik \\
Trialabilitas (mudah tidaknya inovasi untuk dicoba) & 359 & Baik \\
Observabilitas (mudah tidak inovasi untuk diamati) & 120 & Baik \\
\hline Total & 1.294 & \\
\hline
\end{tabular}

Berdasarkan Tabel 5, dapat dilihat bahwa total skor dari keseluruhan variabel pengukuran karakteristik inovasi mengenai pengobatan luka traumatik pada ternak sapi potong menggunakan salep ekstrak tanaman yodium di Desa Mangunrejo Kecamatan Tegalrejo adalah 1.294. Dimana keuntungan relatif berada pada kategori baik, kompatibilitas berada pada kategori cukup baik, kompleksitas berada pada kategori tidak baik, trialabilitas berada pada kategori baik dan observabilitas berada pada ketegori baik. Sesuai pendapat (Hikmah et al., 2019)bahwa karateristik inovasi memiliki pengaruh terhadap persepsi antara lain sikap peternak terhadap inovasi yang disampaikan.

\section{Sikap Peternak}

Sikap peternak mengenai inovasi pengobatan luka traumatik pada ternak sapi potong menggunakan salep ekstrak tanaman yodium diukur menggunakan 7 pertanyaan. Rekapitulasi hasil jawaban responden kategori sikap dapat dilihat pada Tabel 6 sebagai berikut:

Tabel 6. Sikap Peternak

\begin{tabular}{cccc}
\hline \hline Skor & Jumlah (orang) & Persentase (\%) & Keterangan \\
\hline $7-12,6$ & 0 & 0 & Sangat Tidak Setuju \\
$12,7-18,2$ & 0 & 0 & Tidak Setuju \\
$18,3-23,8$ & 4 & 12,5 & Ragu-Ragu \\
$23,9-29,4$ & 18 & 56,25 & Setuju \\
$29,5-35$ & 10 & 31,25 & Sangat Setuju \\
\hline Jumlah & 32 & 100 & \\
\hline
\end{tabular}


Berdasarkan Tabel 6 di atas merupakan hasil rekapitulasi data yang sudah ditabulasikan berdasarkan 32 responden. Peternak yang berada pada kategori ragu-ragu sebanyak 4 orang atau sebesar $12,5 \%$ dan peternak yang berada pada kategori setuju sebanyak 17 orang atau sebesar 56,25\% dan peternak yang berada pada kategori sangat setuju sebanyak 10 orang atau sebesar $31,25 \%$. Responden di Desa Mangunrejo setuju atau bisa dikatakan memberikan umpan balik mengenai inovasi pengobatan luka traumatik pada ternak sapi potong menggunakan salep ekstrak tanaman yodium. Hal ini diduga karena beberapa faktor sebagai berikut:

1) Umur peternak yang menjadi responden $75 \%$ memiliki usia produktif. Tentunya hal ini akan mempengaruhi sikap peternak terhadap materi penyuluhan pengobatan luka traumatik pada ternak sapi potong menggunakan salep ekstrak tanaman yodium (Drs.M.Nur Nasution, 2005)Hal ini juga sesuai dengan pendapat (Karmila, 2013), umur juga erat kaitannya dengan pola pikir peternak dalam menentukan sistem manajemen yang akan di tetapkan dalam kegiatan usaha peternakan.

2) Tingkat pendidikan responden masih tergolong rendah yaitu tamatan SD sebanyak 13 orang dengan indeks persen sebesar 40,62\% dan tamatan SMP sebanyak 11 orang dengan indeks persen sebesar $34,37 \%$, sedangkan untuk tamatan SMA sebanyak 7 orang dengan indeks persen sebesar $21,87 \%$ dan perguruan tinggi satu orang dengan indeks persen sebesar 3,12\%. Tingkat Pendidikan tersebut memberikan dampak pada kemampuan dalam menerima sebuah inovasi. Hal tersebut sesuai dengan pendapat (T. Mardikanto, 2009) bahwa tingkat pendidkan yang dimiliki seseorang akan berpengaruh terhadap kapasitas /keini di metodemampuan belajar yang memerlukan tingkat pengetahuan tertentu untuk dapat memahami suatu teknologi/inovasi.

3) Pengalaman beternak responden kisaran 11-20 tahun yaitu sebanyak 17 orang dengan indeks persen sebesar 53,12\%, kemudian kisaran 31-40 tahun sebanyak 7 orang dengan indeks persen sebesar 21,37\%, selanjutnya kisaran 21-30 tahun dan 41-50 tahun masing-masing satu orang dengan indeks persen sebesar 3,12\%. Hal tersebut sesuai dengan pendapat (Purwo Widiarso et al., 2019) yang menyatakan bahwa umur dan pengalaman beternak akan mempengaruhi respon peternak dalam menjalankan usaha, baik pencegahan penyakit ataupun yang lainnya. serta (Iskandar \& Arfa'i, 2007) menyatakan peternak yang mempunyai pengalaman beternak lebih banyak akan selalu berhati-hati dalam bertindak.

\section{Hasil Korelasi Sederhana (Pearson Product Moment)}

Korelasi sederhana ini dilakukan untuk mengetahui hubungan tingkat kosmopolitan dengan sikap peternak sapi potong di Desa Mangunrejo dan mengetahui hubungan karakteristik inovasi dengan sikap peternak pada pengobatan luka traumatik menggunakan salep ekstrak tanaman yodium di Desa Mangunrejo. Adapun hasil analisis yang diperoleh dapat dilihat pada Tabel 7 sebagai berikut:

Tabel 7. Hasil Korelasi Sederhana (Pearson Product Moment)

\begin{tabular}{|c|c|c|}
\hline$\overline{\text { Uraian }}$ & Tingkat Kosmopolitan & Karakteristik Inovasi \\
\hline Pearson Corelation & 0,395 & 0,355 \\
\hline Sig (2-tailed) & 0,02 & 0,04 \\
\hline $\mathrm{N}$ & 32 & 32 \\
\hline
\end{tabular}

\section{Hubungan Tingkat Kosmopolitan dengan Sikap Peternak Sapi Potong}

Berdasarkan hasil analisis korelasi sederhana (pearson product moment) diperoleh bahwa variabel (X1) tingkat kosmopolitan berhubungan secara signifikan terhadap variabel (Y) sikap. Hal ini dapat dilihat dalam rincian tabel correlations, diperoleh angka Sig. (2-tailed) 0,02 ( $\mathrm{p}<0,05)$, koefisien sebesar 0,395, sehingga hubungan tingkat kosmopolitan dengan sikap peternak sapi potong di Desa Mangunrejo berada dalam kategori korelasi cukup. (Basri, n.d.) menyatakan bahwa hubungan yang berada pada interval $0,25-0,50$ berada pada kategori korelasi cukup. Data tersebut diketahui terdapat hubungan yang positif yang dalam hal ini dimaksudkan cenderung bertambah dan signifikan antara tingkat kosmopolitan dengan sikap peternak sapi potong di Desa Mangunrejo. Semakin tinggi tingkat kosmopolitan peternak maka semakin tinggi pula sikap peternak sapi potong di Desa Mangunrejo (Irmayani, 2013) Hal ini diperkuat oleh pendapat (Suprayitno, 2013) petani yang memiliki akses luas terhadap berbagai informasi akan memiliki informasi yang lebih banyak, sehingga pengetahuan dan wawasan mereka lebih luas, sikap mereka akan lebih baik dan keterampilan mereka akan bertambah baik. (Suharyanto, 2018) menyatakan intensitas penyuluhan merupakan salah satu faktor yang penting 
untuk proses adopsi suatu inovasi. Penyuluhan yang konsisten dan berkelanjutan semestinya memberi dampak pada penambahan pengetahuan dan wawasan petani dalam menerima inovasi. (Padillah et al., 2018) dengan pernyataan bahwa semakin banyak frekuensi penyuluhan akan meningkatkan interaksi petani dengan penyuluh sehingga dapat membuat tingkat persepsi petani terhadap peranan penyuluh dalam rangka meningkatkan produksi padi akan lebih tinggi.

\section{Hubungan Karakteristik Inovasi dengan Sikap Peternak Sapi Potong pada Pengobatan Luka Traumatik Menggunakan Salep Ekstrak Tanaman Yodium}

Berdasarkan hasil analisis korelasi sederhana (pearson product moment) diperoleh bahwa variabel karakteristik inovasi berhubungan secara signifikan terhadap sikap. Hal ini dapat dilihat dalam rincian tabel correlations, diperoleh angka Sig. (2-tailed) $0,04(\mathrm{p}<0,05)$, koefisien sebesar 0,355, sehingga hubungan karakteristik inovasi dengan sikap peternak sapi potong di Desa Mangunrejo berada dalam kategori korelasi cukup. (Basri, n.d.) menyatakan bahwa hubungan yang berada pada interval 0,250,50 berada pada kategori korelasi cukup. Data tersebut diketahui terdapat hubungan yang positif yang dalam hal ini cenderung bertambah dan signifikan antara karakteritik inovasi dengan sikap peternak sapi potong pada pengobatan luka traumatik menggunakan salep ekstrak tanaman yodium di Desa Mangunrejo. Kondisi yang demikian dapat diartikan bahwa semakin tinggi karakteristik inovasi maka semakin tinggi pula sikap peternak sapi potong dalam menerima inovasi yang disampaikan (Dzakiroh et al., 2017). Hal ini didukung dengan pendapat (Nurdayati et al., 2021) bahwa Intensitas penyuluhan tidak berpengaruh secara langsung terhadap persepsi, sedangkan pengaruh secara tidak langsung dari intensitas penyuluhan melalui tingkat pengetahuan berpengaruh signifikan terhadap persepsi sehingga pengetahuan dapat dikatakan memediasi intensitas penyuluhan terhadap persepsi peternak terhadap penggunaan serbuk daun nangka sebagai obat cacing pada domba.

\section{Hasil Korelasi Ganda}

Korelasi ganda ini dilakukan untuk mengetahui hubungan secara simultan yaitu tingkat kosmopolitan dan karakteristik inovasi dengan sikap peternak sapi potong pada pengobatan luka traumatik menggunakan salep ekstrak tanaman yodium di Desa Mangunrejo. Hasil korelasi ganda dapat dilihat pada Tabel 8 berikut:

Tabel 8. Hasil Korelasi Ganda

\begin{tabular}{ccc}
\hline \hline $\boldsymbol{R}$ & $\boldsymbol{R}$ Square & Sig $\boldsymbol{F}$ Change \\
\hline 0,473 & 0,224 & 0,025 \\
\hline
\end{tabular}

Berdasarkan hasil analisis korelasi ganda, diperoleh bahwa tingkat kosmopolitan dan karakteristik inovasi berhubungan secara signifikan terhadap sikap peternak. Hal ini dapat dilihat dalam rincian tabel model summary diperoleh sig $\mathrm{F}$ change sebesar $0,025(\mathrm{p}<0,05)$ dan koefisien korelasi 0,473, sehingga hubungan tingkat kosmopolitan dan karakteristik inovasi dengan sikap peternak sapi potong pada pengobatan luka traumatik menggunakan salep ekstrak tanaman yodium di Desa Mangunrejo berada dalam kategori korelasi cukup. (Basri, n.d.) menyatakan bahwa hubungan yang berada pada interval $0,25-0,50$ berada pada kategori korelasi cukup sedangkan kontribusi secara simultan tingkat kosmopolitan dan karakteristik inovasi dengan sikap peternak sapi potong pada pengobatan luka traumatik menggunakan salep ekstrak tanaman yodium di Desa Mangunrejo sebesar 22,4\% yang diperoleh dari nilai R Square (0,224), yang berarti 77,6\% ditentukan dari faktor lainnya. Faktor yang menjadi penyebab rendahnya kontribusi secara simultan tingkat kosmopolitan dan karakteristik inovasi dikarenakan variabel independen hanya dua yaitu tingkat kosmopolitan dan karakteristik inovasi. (Santoso, 2003) menyatakan bahwa semakin banyak variabel independen yang digunakan maka akan semakin tinggi nilai $\mathrm{R}$ square. Hal ini selaras juga yang disampaikan oleh (Santoso, 2003) yang menyatakan manusia dapat bereaksi terhadap situasi eksternal dan internal yang mempengaruhi karakteristik inovasi.

\section{KESIMPULAN}

Berdasarkan hasil penelitian, maka diperoleh kesimpulan bahwa terdapat hubungan yang signifikan antara tingkat kosmopolitan dengan sikap peternak sapi potong di Desa Mangunrejo sebesar 0,02 $(\mathrm{p}<0,05)$, besarnya koefisien korelasi 0,395 dengan kategori korelasi cukup dan cenderung kearah positif. Terdapat hubungan yang signifikan atara karakteristik inovasi dengan sikap peternak sapi 
potong pada pengobatan luka traumatik menggunakan salep ekstrak tanaman yodium di Desa Mangunrejo sebesar 0,04 ( $\mathrm{p}<0,05)$, besarnya koefisien 0,355 dengan kategori korelasi cukup dan cenderung kearah positif. Terdapat hubungan yang signifikan antara tingkat kosmopolitan dan karakteristik inovasi dengan sikap peternak sapi potong pada pengobatan luka traumatik menggunakan salep ekstrak tanaman yodium di Desa Mangunrejo sebesar 0,025 $(\mathrm{p}<0,05)$. Besarnya koefisien 0,473 dengan kategori korelasi cukup dan konstribusi R square sebesar 22,4\%.

Berdasarkan pelaksanaan kegiatan penelitian, maka diharapkan adanya penelitian lebih lanjut mengenai hubungan tingkat kosmopolitan dan karakteristik inovasi dengan sikap peternak sapi potong potong pada pengobatan luka traumatik menggunakan salep ekstrak tanaman yodium serta adanya penyuluhan kembali mengenai pengobatan luka traumatik menggunakan salep ekstrak tanaman yodium kepada peternak sehingga peternak bias menerapkan inovasi yang diberikan.

\section{DAFTAR PUSTAKA}

Arikunto. (2013). Prosedur Penelitian Suatu Pendidikan Praktik. Jakarta: PT Rineka Cipta.

Basri, S. (n.d.). Uji Korelasi Pearson - Seta Basri Menulis Terus | PDF. Retrieved January 4, 2022, from https://id.scribd.com/doc/201890737/Uji-Korelasi-Pearson-Seta-Basri-Menulis-Terus

Drs.M.Nur Nasution, M. S. (2005). Manajemen Mutu Terpadu ( Total Quality Management) Edisi Kedua (Kedua). Ghalia Indonesia.

Dzakiroh, D., Wibowo, A., \& Ihsaniyatin, H. (2017). Sikap Afektif Penyuluh Terhadap Website Cyber Extension sebagai Sumber Informasi Penyuluhan Pertanian di Kabupaten Karanganyar. https://digilib.uns.ac.id/dokumen/detail/66678/Sikap-Afektif-Penyuluh-Terhadap-WebsiteCyber-Extension-sebagai-Sumber-Informasi-Penyuluhan-Pertanian-di-Kabupaten-Karanganyar

Hikmah, E. K., Nurdayati, \& Puji Hartati. (2019). Persepsi Peternak Terhadap Teknologi Pembuatan Telur Asin Menggunakan Alat Pemanas Sederhana | Hikmah | Jurnal Pengembangan Penyuluhan Pertanian. http://jurnal.polbangtanyoma.ac.id/index.php/jp3/article/view/71

Irmayani. (2013). Analisis Tingkat Motivasi Peternak Sapi Perah Di Kabupaten Enrekang Dan Faktor Yang Mempengaruhinya.Skripsi. Fapet.Unhas..

Iskandar, I., \& Arfa'i. (2007). Oleh: Ismet Iskandar dan Arfa ï Fakultas Peternakan Universitas Andalas Padang RINGKASAN - PDF Free Download. https://adoc.pub/oleh-ismet-iskandar-danarfai-fakultas-peternakan-universita.html

Junaidi. (2007). Pemahaman Tentang Adopsi, Difusi dan Inovasi Teknologi dalam Penyuluhan Pertanian.

Karmila. (2013). Faktor-Faktor yang Menentukan Pengambilan Keputusan Peternak dalam Memulai Usaha Peternakan Ayam Ras Petelur di Kecamatan Bissappu Kabupaten Bantaeng. Skripsi. Fakultas Peternakan. Universitas Hasanuddin. Makassar.

Khasanah, W. (2008). Hubungan faktor-faktor sosial ekonomi petani dengan tingkat adopsi inovasi teknologi budidaya tanaman jarak pagar (jatropha curcas L.) Di Kecamatan Lendah Kabupaten Kulon Progo. https://digilib.uns.ac.id/dokumen/7610/Hubungan-faktor-faktor-sosial-ekonomipetani-dengan-tingkat-adopsi-inovasi-teknologi-budidaya-tanaman-jarak-pagar-jatropha-curcasL-Di-Kecamatan-Lendah-Kabupaten-Kulon-Progo

Mardikanto, T. (2009). Konsep Umum Penyuluhan Pertanian.

Mardikanto, T. dan S. S. (1982). Pengantar Penyuluhan Pertanian. Hapsara, Surakarta.

Nurdayati, N., Widiarso, B. P., Pratiwi, D. E., \& Wijaya, F. M. P. (2021). Pengetahuan sebagai Mediasi Intensitas Penyuluhan Terhadap Persepsi Peternak pada Penggunaan Serbuk Daun Nangka sebagai Obat Cacing pada Domba. Jurnal Penyuluhan, 17(1), 25-39. https://doi.org/10.25015/17202132921

Padillah, P., Purnaningsih, N., \& Sadono, D. (2018). Persepsi Petani tentang Peranan Penyuluh dalam Peningkatan Produksi Padi Di Kecamatan Tabir Kabupaten Merangin Provinsi Jambi | Jurnal Penyuluhan. https://journal.ipb.ac.id/index.php/jupe/article/view/17778 
Padmowiharjo. (2002). Metode Penyuluhan Pertanian. Univeritas Terbuka Jakarta.

Purwo Widiarso, B., Wahidah Mubarokah, W., Pembangunan Pertanian Yogyakarta Magelang, P., Mgelang-Kopeng Km, J., \& Tegalrejo Magelang, P. (2019). Respon Peternak terhadap Pencegahan dan Pengobatan Penyakit Cacing Gastrointestinal Pada Kambing di Desa Klopo Kecamatan Tegalrejo Kabupaten Magelang. Jurnal Ilmu Peternakan Dan Veteriner Tropis (Journal of Tropical Animal and Veterinary Science), 9(2), 76-82. https://doi.org/10.30862/JIPVET.V9I2.68

Putri cahyani, A., Purwo widiarso, B., Wahidah Mubarokah, W., \& Pembangunan Pertanian Yogyakarta Magelang Jalan Magelang-Kopeng Km, P. (2021). Aktivitas Salep Ekstrak Daun Sirsak (Annona Muricatal.) Dalam Penyembuhan Scabies Pada Kambing Secara In Vivo The Activity of Soursop (Annona Muricatal) Leaf Extract Oinment in Scabies Healing of Sheep In Vivo. 18(31), 32-40. http://jurnal.polbangtanyoma.ac.id/index.php/jp3/index

Rogers, E. M. (1996). Diffutions of innovations. 3rd Edition. New York: Tahune Free Pass A Division of Macmillan Publishing Co, Inc.

Santoso, B. A. . (2003). Tutorial dan Solusi Pengolah Data Regresi. Jakarta. EGC.

Siregar, S. (2013). Metode Penelitian Kuantitatif. Jakarta: PT Fajar Interpratama Mandiri.

Sugeng, Y. B. (n.d.). Beternak Sapi Potong. Penebar Swadaya, Jakarta. In 2007.

Suharyani, A., \& Oktoriana, S. (2018). Pengaruh Tingkat Imitasi Dan Kosmopolitan Wanita Tani Terhadap Keputusan Pengelolaan Usahatani. Agrifo: Jurnal Agribisnis Universitas Malikussaleh, 3(2), 1-7. https://doi.org/10.29103/AG.V3I2.1114

Suharyanto, nFN-. (2018). FAKTOR-FAKTOR YANG MEMPENGARUHI PERSEPSI PETANI TERHADAP KEBIJAKAN PERLINDUNGAN LAHAN PERTANIAN PANGAN BERKELANJUTAN DI PROVINSI BALI. Jurnal Pengkajian Dan Pengembangan Teknologi Pertanian, 20(2), 111-124. https://doi.org/10.21082/JPPTP.V20N2.2017.P111-124

Suprayitno, A. R. (2013). Model peningkatan partisipasi petani sekitar hutan dalam mengelola hutan kemiri rakyat (Kasus pengelolaan hutan kemiri kawasan pegunungan Bulusaraung kabupaten Maros provinsi Sulawesi Selatan). http://repository.ipb.ac.id/handle/123456789/46616

Widiarso, B. P., Kurniasih, K., Prastowo, J., \& Nurcahyo, W. (2018). Morphology and morphometry of Haemonchus contortus exposed to Gigantochloa apus crude aqueous extract. Veterinary World, 11(7), 921. https://doi.org/10.14202/VETWORLD.2018.921-925

Widiarso BP, Dewi DA, Sarwendah K, \& Pratiwi, D. (2021). In vitro potency of a crude aqueous extract of artocarpus heterophyllus leaves as an anthelmintic against haemonchus contortus in jawarandu goats.Advances in Animal and Veterinary Science.9(9):1498-1503

Widyaningrum. (2005). Ilmu Produksi Ternak Potong dan Kerja. Semarang University Press. Semarang.

Wiriaadmadja, M. I., Alim, S., \& Winaryanto, S. (2016). HUBUNGAN KARAKTERISTIK INOVASI DENGAN TINGKAT PENGETAHUAN DAN SIKAP PETERNAK PADA PENYULUHAN PEMBUATAN SILASE UNTUK TERNAK DOMBA. 